\title{
Performance and determination of Concentration Ratio for a parabolic solar concentrator using a thermographic technique
}

Desempeño y determinación de la relación de concentración de un concentrador solar parabólico mediante termografías

Fabián Cano Ardila (iD) 1 Juan David Giraldo Quintero (iD ${ }^{1 *}$, Sergio Agudelo Flórez (iD ${ }^{2}$

${ }^{1}$ Grupo de Ciencia y Tecnología del Gas-GASURE, Departamento de Ingeniería Mecánica, Universidad de Antioquia. Calle 67 \# 53-108. C. P. 050010. Medellín, Colombia.

2Departamento de Ingeniería Mecánica, Grupo de Energía Alternativa GEA, Universidad de Antioquia. Calle 67 \# 53-108.

C. P. 050010 . Medellín, Colombia.

\section{CITE THIS ARTICLE AS:}

F. Cano, J. D Giraldo, and S.

Agudelo. "Performance and

determination of

Concentration Ratio for a

parabolic solar concentrator

using a thermographic

technique", Revista Facultad de

Ingeniería Universidad de

Antioquia, no. 100, pp.

133-141, Jul-Sep 2021.

[Online]. Available: https:

//www.doi.org/10.17533/

udea.redin. 20210530

\section{ARTICLE INFO:}

Received: October 26, 2020

Accepted: May 14, 2021

Available online: May 14, 2021

\section{KEYWORDS:}

Solar energy; solar heating; solar radiation; thermal efficiency; solar collector

Energía solar; calefacción solar; radiación solar; eficiencia térmica; colector solar
ABSTRACT: This work addresses the methodology to determine the exact concentration ratio (CR) for a parabolic solar concentrator (PSC) using thermographic imaging. The value of $C R$ is commonly given in terms of the area of the receiver and not in terms of the area of the image produced by the concentrator on the receiver surface. With thermographic analysis, it is possible to know the real image generated by the PSC on the receiver, which helps to have a precise calculation of $\mathrm{CR}$. It is important to measure the real CR not only for manufacturing purposes but also for the maintenance of solar concentrators, since its miscalculation lowers their energy efficiency or lifespan. In experiments, the real image on the receiver is divided into 4 regions, stratified with an equal temperature difference for each one. With this consideration, CR varied from 20 to 151. To complete the analysis, the energy efficiency is calculated. Since heating is a non-stationary process, thermal efficiency fluctuated during the time of experimentation, having a peak of $25 \%$ and a mean value of $15.3 \%$. The irregularities of curvature in the concentrators significantly deteriorate the uniformity of the radiation flux and the energy efficiency due to unused areas of concentration.

RESUMEN: Este trabajo aborda una metodología para determinar el factor de concentración (FC) exacto para un concentrador solar parabólico (CSP) utilizando cámara termográfica. El valor del FR se da comúnmente en términos del área del receptor y no en términos del área de la imagen producida por el concentrador en la superficie del receptor. Con el análisis termográfico es posible conocer la imagen real generada por el CSP sobre el receptor, lo que ayuda a tener un cálculo preciso del FC. Es importante disponer de metodologías para medir el FC real no sólo en la fabricación sino también en el mantenimiento de los concentradores solares, ya que su cálculo erróneo puede provocar disminuciones en la eficiencia energética o afectar a su vida útil. En los experimentos, la imagen real sobre el receptor se dividió en 4 regiones, estratificadas con igual diferencia de temperatura cada una. Con esta consideración, el FC varió de 20 a 151. Por otro lado, se calculó la eficiencia energética para completar el análisis. Dado que el calentamiento es un proceso no estacionario, la eficiencia térmica fluctuó durante el tiempo de experimentación, obteniendo un pico de $25 \%$ y un valor promedio del $15,3 \%$. Las irregularidades de curvatura en los concentradores deterioran significativamente la uniformidad del flujo de radiación y la eficiencia energética debido a las zonas de concentración no utilizadas.

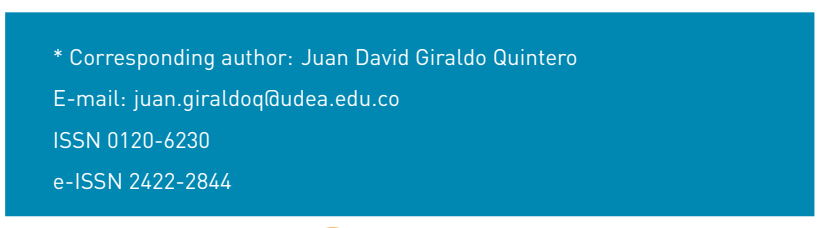


Nomenclature:

\begin{tabular}{|c|c|}
\hline$q_{o}(\mathrm{~J})$ & $\begin{array}{l}\text { Rate of useful heat absorbed by the } \\
\text { water }\end{array}$ \\
\hline$q_{i}(\mathrm{~J})$ & $\begin{array}{l}\text { Solar thermal rate received by the } \\
\text { collector }\end{array}$ \\
\hline$A_{c}\left(\mathrm{~m}^{2}\right)$ & Collector area \\
\hline$I\left(\mathrm{~W} / \mathrm{m}^{2}\right)$ & Solar irradiation \\
\hline$M_{w}(\mathrm{~kg})$ & Mass of water \\
\hline$A_{e f f, c}\left(\mathrm{~m}^{2}\right)$ & $\begin{array}{l}\text { Surface area that actually reflects the } \\
\text { solar radiation reaching the } \\
\text { concentrator }\end{array}$ \\
\hline$A_{\text {eff }, r e c}\left(\mathrm{~m}^{2}\right)$ & $\begin{array}{l}\text { Actual incidence area of the } \\
\text { concentrated radiation on the receiver } \\
\text { surface }\end{array}$ \\
\hline$A_{r e c, a}\left(\mathrm{~m}^{2}\right)$ & $\begin{array}{l}\text { Apparent area of the opaque receiving } \\
\text { plate }\end{array}$ \\
\hline$A_{\text {rec }}\left(\mathrm{m}^{2}\right.$ & Real area of the receiving plate \\
\hline$q^{\prime \prime}\left(\mathrm{W} / \mathrm{m}^{2}\right)$ & Radiation flux \\
\hline$\varepsilon$ & Emissivity of the opaque surface \\
\hline$T_{s}\left({ }^{\circ} \mathrm{C}\right)$ & Surface temperature \\
\hline$\sigma\left(\mathrm{W} \cdot \mathrm{m}^{-2} \cdot \mathrm{K}^{-4}\right)$ & $\begin{array}{l}\text { Stefan-Boltzmann constant which takes } \\
\text { a value of } 5.67037 \times 10^{-8} \mathrm{~W} \cdot \mathrm{m}^{-2} \cdot \mathrm{K}^{-4}\end{array}$ \\
\hline$Q(\mathrm{~W})$ & Radiation power over the opaque plate \\
\hline$\eta$ & $\begin{array}{l}\text { Global energy efficiency of the } \\
\text { concentrator }\end{array}$ \\
\hline$C R$ & Concentration ratio \\
\hline
\end{tabular}

\section{Introduction}

Global warming is one of the main issues that the world is facing nowadays. The general dependence on fossil fuels has a great impact due to the enormous amount of greenhouse gas emissions; $\mathrm{CO}_{2}$ is mostly responsible for this problem [1, 2]. In 2015, 179 countries came to an agreement for the implementation of sustainable development strategies to reduce pollutant emissions and maintain the rise in global temperature below $2{ }^{\circ} \mathrm{C}$ in comparison with the pre-industrial levels [3]. One of these strategies is to contribute to the usage of renewable energy in the global share of power generation. Solar power is one of the most promising alternatives to face energy needs in the future, and solar concentrators can be important for the rational and efficient utilization of this source of energy [1, 4-7].

Generally, these are designed to convert solar radiation into thermal energy that can be stored in a working fluid $[7,8]$. On the one hand, concentrators can be coupled to complex systems like electrolyzers and solar combustors to produce and burn hydrogen or preheat combustion air. On the other hand, they can also be coupled to photovoltaic (PV) systems in order to improve power generation and reduce costs associated with $P V$ modules. This gives the solar concentrator a wide range of applications and a potential impact on the renewable energy sources field [9-11].

In the study of solar concentrators, the concentration ratio $(C R)$ is one of the most important parameters, and it can be obtained using optical techniques [12, 13]. Systems like dish concentrators, solar thermal plants, and solar cookers require such optical analysis since their efficiency must be determined and depends directly on the value of CR [14]. Commonly, CR is calculated in terms of the area of the receiver and not in terms of the area of the real image produced by the concentrator on the receiver surface [15-17]. This is mainly caused by irregularities on the surface of the concentrator ending in non-homogeneous heat flux to the receiver [18]. The classical calculation approach of CR yields an error in the expected concentrated solar radiation and directly impacts the computations of variables as thermal efficiency. Having an accurate value of CR in the manufacturing and maintenance of solar concentrators would be important since its miscalculation can lead to non-optimal performance and a shorter lifetime of concentrators.

On the analysis of solar concentrators, CR is commonly measured following the geometrical characteristics of concentrators. For example, for compound parabolic concentrators (CPC), a proportional and nearly linear relationship between the heat flux on the receiver and the concentration ratio of the CPC is attained [19]. In another study, an optical analysis is performed with a CCD camera for a multi-segment plate (MSP) concentrator on a solar concentration photovoltaic (CPV) system. The CR is calculated following the geometry of the concentrator and the receiver for this optical analysis. The images taken with the CCD camera are used to measure the concentration uniformity over the receiver [20]. For optimizing the parabolic trough solar collector, three design variables are varied: the receiver diameter, the collector aperture width, and the rim angle. Being directly affected by these variables, the CR is measured based on the geometric relation between the aperture area and the receiver area (i.e., using its actual geometry) [21].

The above-mentioned studies are a representative sample of the state of art on solar concentrators, where the CR is measured based on the actual geometry of concentrators instead of being calculated with the real image generated on the receiver. In this context, the 
present work will contribute to the development of a new methodology to measure CR more accurately.

This work aims to use thermal imaging to calculate CR using the real image generated by the concentrator on the receiver. The computed $\mathrm{CR}$ is subsequently used to calculate the thermal efficiency, which reflects the behavior of the concentrator. It is suggested to use thermal imaging due to the fact that the radiation can be absorbed by the receiver and transformed into thermal energy, which the thermographic camera can capture. This practice is commonly used in research and industry to establish heat transfer across surfaces or for hot/cold surface analyses [22].

Therefore, in this work, the concentration ratio (CR) of a parabolic solar concentrator is calculated using thermographic images. Thermographic images are used not only to identify whether the radiation is coming from the concentrator but also to check if the projection on the receiver is uniform. The images are treated using two different MATLAB codes. An energy balance is also performed to estimate the performance of the thermal energy along with the heating of the working fluid, which is water.

\section{Methodology}

\subsection{Experimental setup}

In order to determine the efficiency of the solar concentrator, the experimental setup shown in Figure 1a is used. The concentrator is an elliptic paraboloid with a 0.33 $\mathrm{m}$ semi-major axis, $0.3 \mathrm{~m}$ semi-minor axis, and $0.06 \mathrm{~m}$ depth. It is made of a steel sheet of $1 \mathrm{~mm}$ thickness, and it is fully covered with mirror pieces of $1.5 \mathrm{~cm} \times 1.5 \mathrm{~cm}$ and 3 $\mathrm{mm}$ of thickness. As shown in Figure $1 \mathrm{~b}$, the concentrator is directed normal to the incident solar radiation.

The working fluid used in the experiments consists of 850 $\mathrm{g}$ of water. Its temperature is constantly measured using a K-type thermocouple in order to obtain a time-dependent function of temperature. Solar irradiation is measured by orienting a Kipp \& Zonen CM3 pyrometer directly to the sun. Finally, the global energy efficiency is calculated using Equation 1 [23].

$$
\eta=\frac{q_{o}}{q_{i}}=\frac{M_{W} \cdot C_{W} \cdot \Delta T_{W}}{A_{C} \cdot I \cdot \Delta t}
$$

Where,
$q_{o}: \quad$ Useful heat rate absorbed by water.
$q_{i}$ : $\quad$ Solar thermal rate received by the collector.

$A_{c}$ : $\quad$ Surface area of the collector.

I : $\quad$ Solar irradiation.

$M_{W}$ : Mass of water.

$C_{W}: \quad$ Water-specific heat.

$\Delta T_{W}: \quad$ Water temperature change.

$\Delta t: \quad$ Time difference.

The experiments were performed in Medellin, Colombia, during July at 1479 masl (meters above sea level) and between 11:30 and 13:10 with ambient conditions of $T$ $=26^{\circ} \mathrm{C}$ and $P=85.4 \mathrm{kPa}$. The atmosphere was clear and solar irradiation was almost constant at $951 \pm 37$ $\mathrm{W} / \mathrm{m}^{2}$ during this time interval. Each experiment was performed five times. The approximate time taken by each experiment was 108 minutes.

In order to measure the concentration ratio (CR), the receiver of Figure $1 a$ is changed to an opaque plate, as seen in Figure $1 \mathrm{~b}$. The receiving plate has dimensions of $0.3 \mathrm{~m} \times 0.3 \mathrm{~m} \times 0.02 \mathrm{~m}$ and is made of $3 \mathrm{~mm}$ plastic sheets fixed with silicone. A system circulating water at $22{ }^{\circ} \mathrm{C}$ is implemented to cool down the opaque plate. The water flow is regulated so that the concentrated radiation only heats up the area of incidence and not the rest of the opaque plate by conduction mechanism. The opaque plate is placed in the focus of the elliptic paraboloid and then adjusted to be normal to the incident solar radiation.

During thermographic analysis, we used a TESTO $8769 \mathrm{~Hz}$ camera. The temperatures of the concentrator are recorded to recognize which area reflects most of the solar radiation. The temperatures of the receiving surface of the opaque plate are also recorded in order to calculate the area of the image generated by the concentrator on the receiver.

\subsection{Image processing}

The images are treated using two MATLAB codes. In Figure 2, one of the codes is used in order to determine the surface area of the concentrator that redirects the solar radiation. Figure $2 \mathrm{~b}$ shows the thermographic image of the solar concentrator. Successively, a binary image with a value of 1 in all the pixels within the elliptical profile is displayed in Figure 2c. This procedure is done to define the region of interest (ROI) of the concentrator.

Figure $1 \mathrm{~b}$ and Figure $2 \mathrm{a}$ show that the configuration of the experimental setup allows the opaque plate to produce a shadow over the surface of the concentrator; this contributes to a lower temperature in that region, and therefore, less solar radiation is reflected. Thus, pixels within the ROl that have a lower temperature than the 


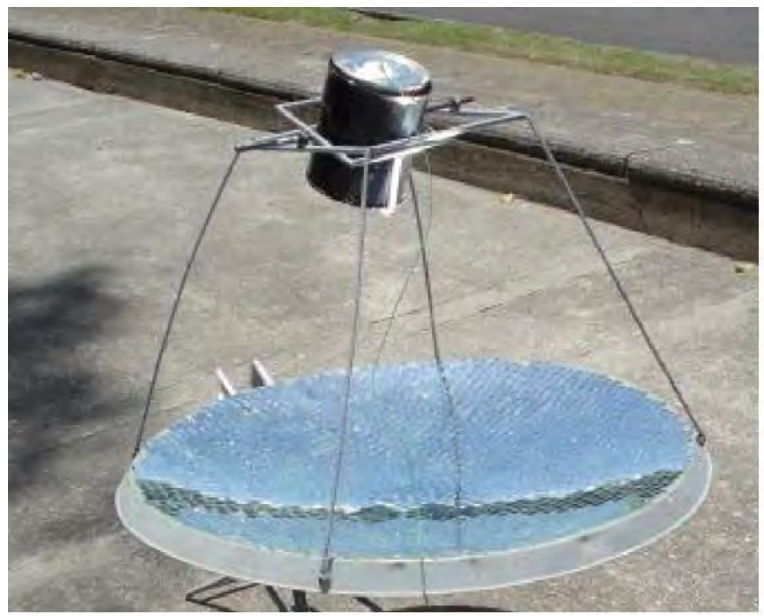

a)

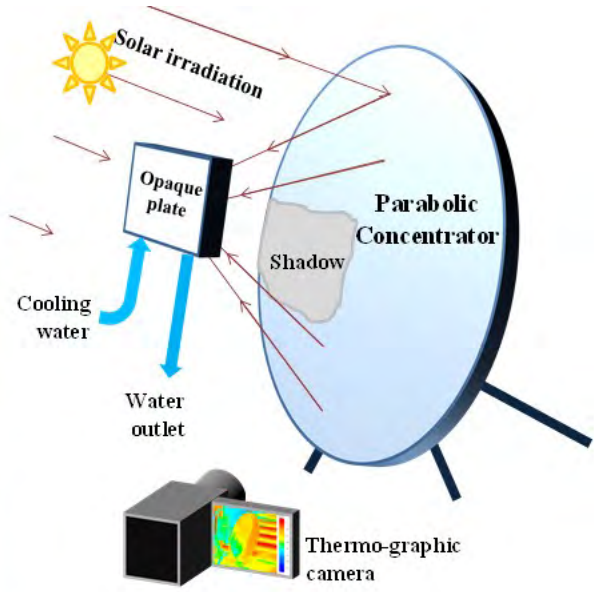

b)

Figure 1 a) Experimental setup used to determine the efficiency of the solar concentrator b) Experimental setup to determine the concentration ratio

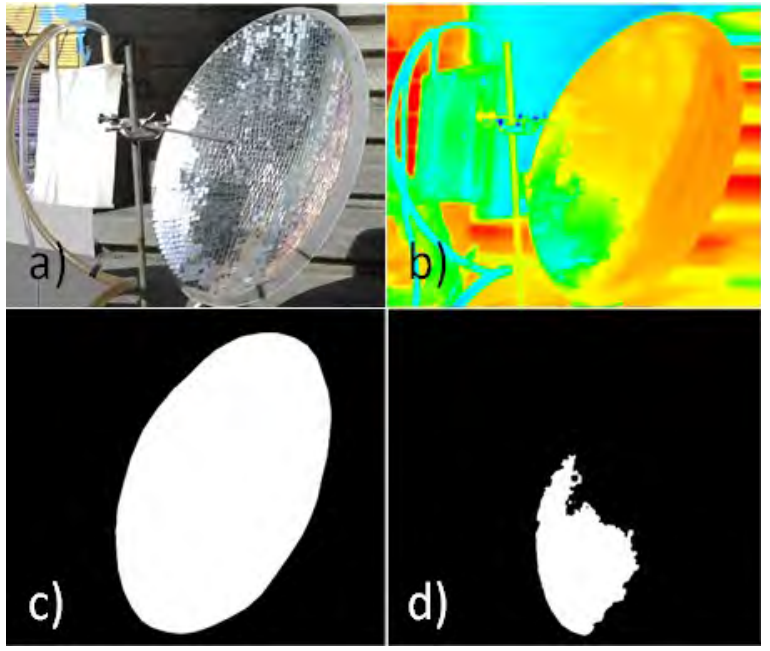

Figure 2 Concentrator image processing

rest of the surface are shown in Figure $2 \mathrm{~d}$. Those pixels resemble the shadow area, which is subtracted from the receiving area of the concentrator to find the effective area.

The ratio of the concentrator area reflecting the solar radiation to the concentrator area is calculated using Equation 2.

$$
R=\frac{A_{c, a}-A_{\text {shadow }, a}}{A_{c, a}}
$$

Where $A_{c, a}$ is the apparent collector area in pixels and is determined using Figure 2c. Ashadow, a is the apparent shadow area in pixels and is produced by the opaque plate on the concentrator. Since there are apparent areas in Figure $3 c$ and $3 d$ that do not consider the non-perpendicularity of the photograph of the concentrator, $R$ is required. The Equation 3 is employed to determine the area in $\mathrm{m}^{2}$ that reflects the solar radiation reaching the concentrator $\left(A_{e f f, c}\right)$.

$$
A_{e f f, c}=R \cdot A_{c}
$$

Where $A_{c}$ is the real area of the elliptical paraboloid, which is $0.311 \mathrm{~m}^{2}$. The surface area of the image generated by the concentrator on the surface of the opaque receiving plate is determined using the image processing of Figure 3.

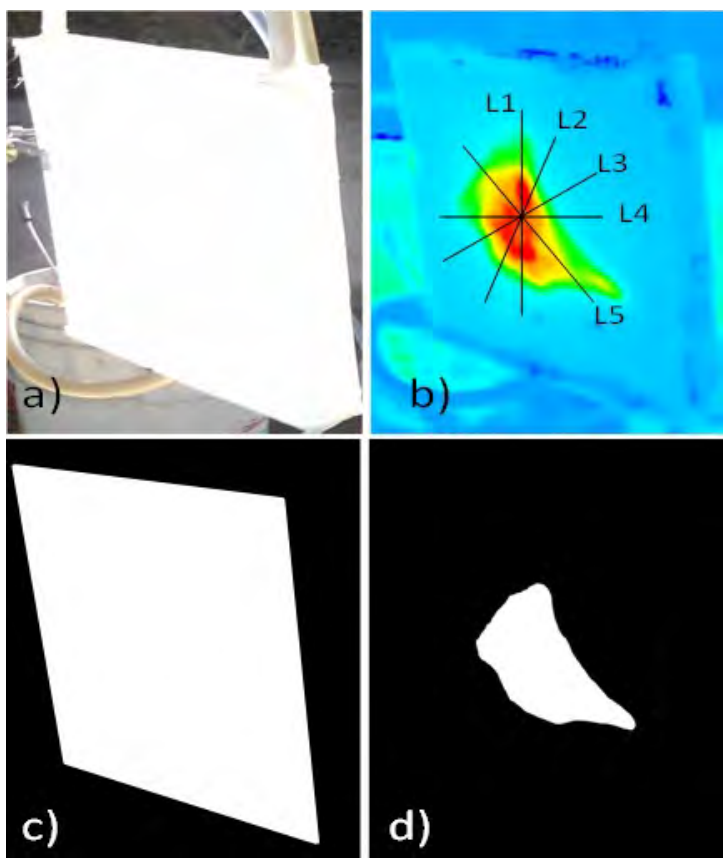

Figure 3 Image processing in the opaque plate

Figure $3 b$ shows the surface of the opaque plate; the red color indicates high temperatures. The ROI of this Figure 
is determined using Figure $3 c$. Figure $3 c$ is a binary image employed to execute a FOR cycle in which the area of incidence of the concentrated radiation is computed. It can be seen that there are areas that are hotter than others. Then it was necessary to establish 4 isothermal lines to scrutinize the impact of radiation on the receiver $\left(45^{\circ} \mathrm{C}\right.$, $55^{\circ} \mathrm{C}, 65^{\circ} \mathrm{C}$ and $75^{\circ} \mathrm{C}$ ). With this information, the area of incidence of the concentrated radiation on the opaque plate is determined in Figure 3d.

In this investigation, it was not possible to take pictures perpendicular to the opaque plate surface. Consequently, it is necessary to determine the ratio between the apparent surface area of the opaque plate and the apparent incidence area of the radiation. The real area of impact of the radiation is calculated using Equation 4 in order to determine the CR.

$$
A_{e f f, r e c}=A_{r e c} \frac{A_{i n c, a}}{A_{r e c, a}}
$$

Where $A_{\text {eff,rec }}$ is the actual area of incidence of the concentrated radiation on the opaque plate, $A_{i n c, a}$ is the apparent area of incidence of radiation in pixels found in Figure $3 \mathrm{~d}$ after implementing the isothermal lines, $A_{\text {rec }, a}$ is the apparent area of the opaque receiving plate shown in Figure 3c. Finally, Arec is the real area of the receiving plate and is the one used to calculate $C R$. It has a value of $0.09 \mathrm{~m}^{2}$. The concentration ratio $(C R)$ of the solar concentrator is then calculated using Equation 5.

$$
C R=\frac{A_{e f f, c}}{A_{\text {eff,rec }}}
$$

Five temperature lines are depicted in Figure $3 b$ to illustrate the homogeneity of the radiation flux. The radiation flux $q^{\prime \prime}$ is computed at each temperature by means of Equation 6 consistent to Stefan-Boltzmann's law.

$$
q^{\prime \prime}=\frac{Q}{A_{\text {eff }, \text { rec }}}=\sigma \cdot T_{s}^{4}
$$

Where the emissivity of the opaque surface has a value of $0.95, \sigma=5.67037 \times 10^{-8} \mathrm{~W} \cdot \mathrm{m}^{-2} \cdot \mathrm{K}^{-4}$ is the Stefan-Boltzmann constant, and $T_{s}$ is the surface temperature. $Q$ is the radiation power over the opaque plate by considering the area of incidence of the concentrated radiation calculated using Equation 4.

\section{Results}

\subsection{Energy efficiency analysis}

Solar irradiation over the surface of the concentrator is shown in Figure 4. According to the graph, the concentrator received mean solar irradiation of $951 \pm$ $37 \mathrm{~W} / \mathrm{m}^{2}$. As time progresses, the water temperature increases due to the concentrated energy on the receiver surface, while the ambient temperature remains constant at $26^{\circ} \mathrm{C}$. The water reaches a maximum temperature of $83^{\circ} \mathrm{C}$ in $108 \mathrm{~min}$.

The energy efficiency behavior is presented in Figure 5. Energy efficiency increases with the temperature of the water, reaching a maximum value of $25 \%$ when the water is at $47^{\circ} \mathrm{C}$ after 18 minutes from the start-up of the experiment. This is caused by useful heat absorbed, which increases with the temperature difference between water and ambient. After $47^{\circ} \mathrm{C}$, water starts evaporating faster, and thermal effects like conduction, convection, and radiation take place. Energy losses are larger from the receiver surface to the ambient, reducing the useful heat absorbed, and the energy efficiency starts decreasing to reach a value of $11 \%$ when water is almost evaporating at $83^{\circ} \mathrm{C}$ for Medellin conditions. The mean value of energy efficiency was $15.3 \%$.

Thermal losses can be reduced using better materials for the solar concentrator, such as highly reflective materials for the collector, good design and high absorptivity, and low emissivity materials for the absorber. However, irregularities in the curvature of the collector can lead to a bad concentration of solar radiation on the absorber surface and generate big energy losses too. Improving the concentration factor is equally important, and it is mainly originated from collector manufacture problems. In an optimal operation zone, a decrease in the $C R$ of $60 \%$ can lead to a reduction of $5 \%$ in overall efficiency [15]. $C R$ is critical in the design of the solar concentrators. Irregularities in the concentration minimize the concentration ratio and, as previously mentioned, affect the overall concentrator efficiency.

\subsection{Concentration ratio analysis}

The effective reflection area of the solar concentrator is $78 \%$ of the total area of the parabolic concentrator, as can be seen on Table 1. Thus, the shadow generated by the opaque plate on the concentrator demonstrates a positive effect. Figure 6 shows the results of the thermographic image processing of the surface of the opaque receiving plate.

Table 1 Results obtained from image processing for the solar concentrator

\begin{tabular}{cc}
\hline Parameter & Value \\
\hline$R=\frac{A_{c, a}-A_{\text {shadow }, a}}{A_{c, a}}$ & $0.7776 \pm 0.0039$ \\
$A_{\text {eff }, c}$ & $0.2419 \pm 0.0004 \mathrm{~m}^{2}$ \\
\hline
\end{tabular}

Figure ba shows the area of the image generated by the solar concentrator on the opaque receiving plate. 


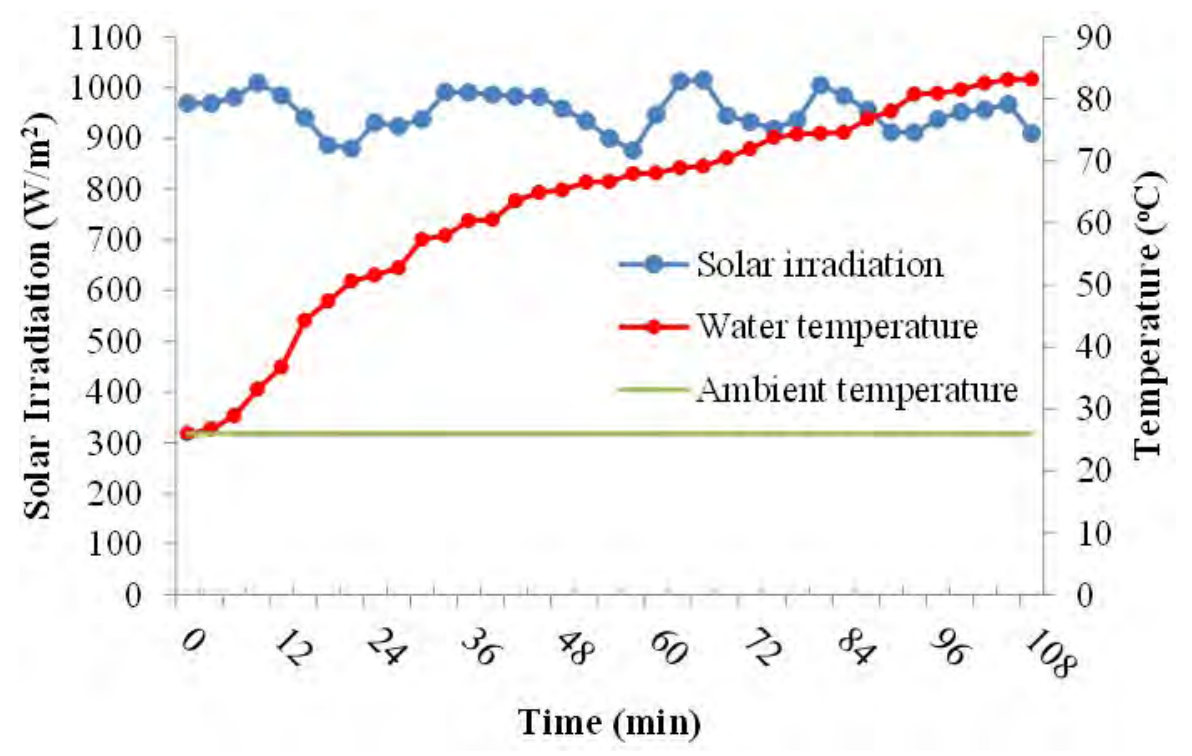

Figure 4 Solar irradiation, water temperature, and ambient temperature vs. time

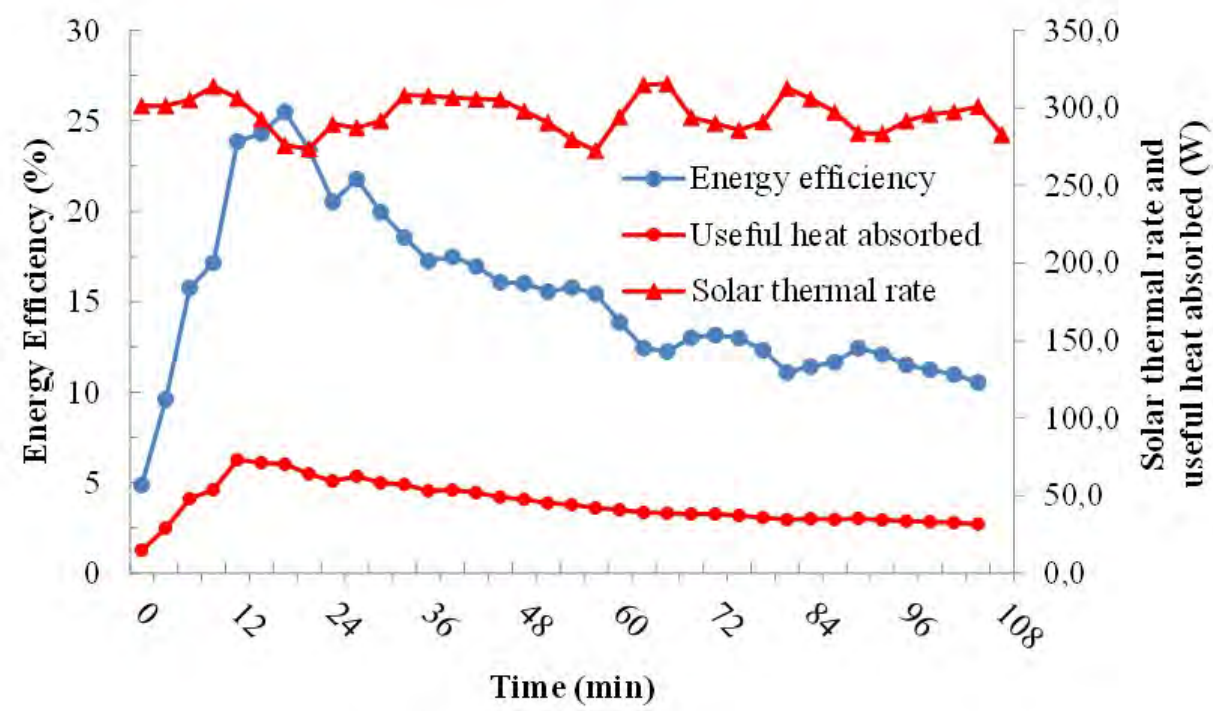

Figure 5 Energy efficiency, useful heat absorbed, and solar thermal rate vs. water temperature

Some areas are hotter than others when the system is on steady-state. On the other hand, it is clear that the morphology of the image is irregular and not symmetrical. This is caused by the irregularities on the concentrator surface, which generate a non-uniform radiation flux, and consequently, a non-uniform temperature profile. In the analysis, four regions are selected. The green region, for example, represents the area with a temperature higher than $45^{\circ} \mathrm{C}$; the yellow region resembles the area where the temperatures are greater than $55^{\circ} \mathrm{C}$, and the hottest part is the red region $\left(\mathrm{T}>75^{\circ} \mathrm{C}\right)$. The maximum incidence area is $124 \mathrm{~cm}^{2}$.
In the hotter areas, the concentrated radiation flux is higher. For the different regions specified in Figure 6, the concentration ratio $(C R)$ is calculated. $C R$ is greater for the warmer regions, as shown in Figure 6b. According to the four selected regions, $C R$ is lower for the larger areas and varies from 20 to 151 as the radiation flux varies.

Figure 7 shows that varying the position also varies the radiation flux. As can be seen, the radiation is not symmetrical for all lines due to the irregularities of the parabolic concentrator. The radiation flux is further concentrated in the center, as shown in Figure 6b. For this reason, there will be a higher temperature in the center, 

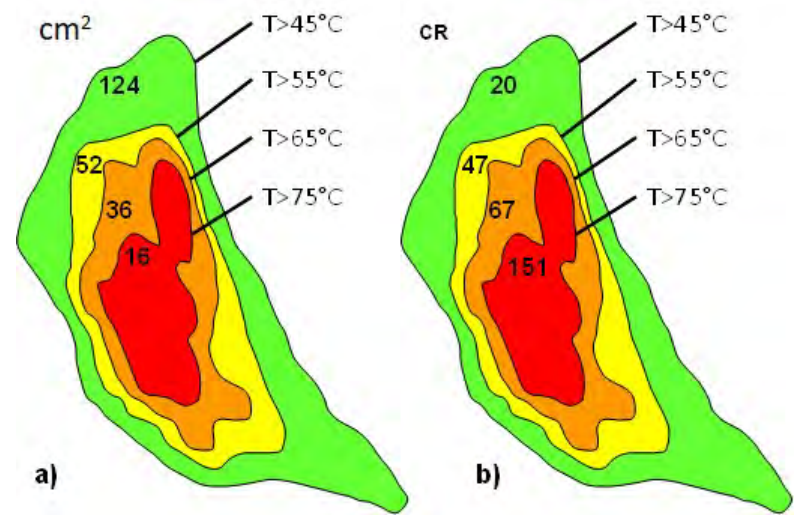

Figure 6 Area $\left(\mathrm{cm}^{2}\right)$ and the concentration ratio $(C R)$ as a function of the temperature in the opaque plate

which also has a higher concentration factor, as shown in Figure 8. In fact, in Figure 7, the radiation flux is shown on the five temperature lines that are specified in Figure $3 \mathrm{~b}$.

Figure 8 shows that by increasing $C R$, the emitted radiation flux from an opaque plate also increases, but there is a contrary trend regarding the power. The radiation flux increases on an interval from $700 \mathrm{~W} \cdot \mathrm{m}^{2}$ to $830 \mathrm{~W} \cdot \mathrm{m}^{2}$ for $C R$ with values between 20 and 151 , respectively. In the same interval, power decreases from $8.7 \mathrm{~W}$ to $1.3 \mathrm{~W}$.

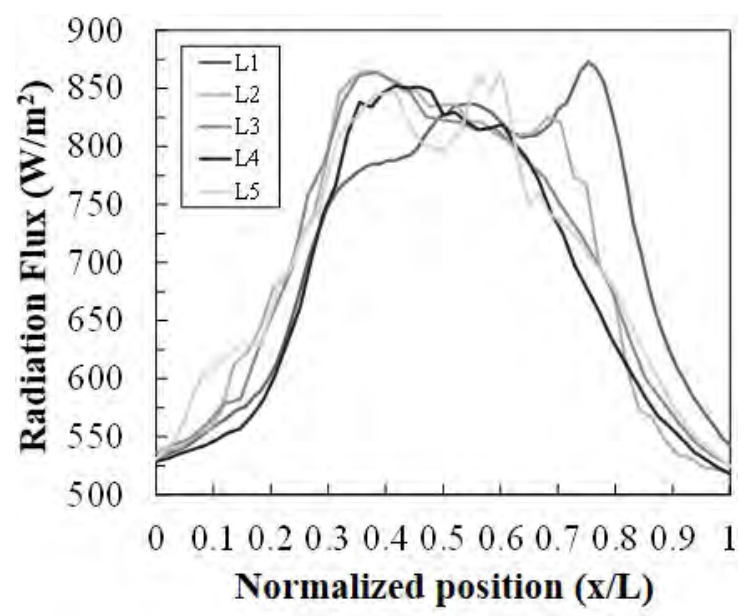

Figure 7 Radiation flux over five temperature lines in the area of radiation concentration

When the $C R$ and the radiation flux reach their maximum, the power decreases to its minima; this is caused by the difference in the availability of the area. For a higher $C R$, the area available is lower. Thus, for a $C R$ of 151 , a power of $1.3 \mathrm{~W}$ is obtained, which represents $15 \%$ of the total power. On the other hand, for a $C R$ of $47.4 \mathrm{~W}$ of power is obtained, representing $46 \%$ of the total power. Although the remaining area is between $45^{\circ} \mathrm{C}$ and $55^{\circ} \mathrm{C}$,

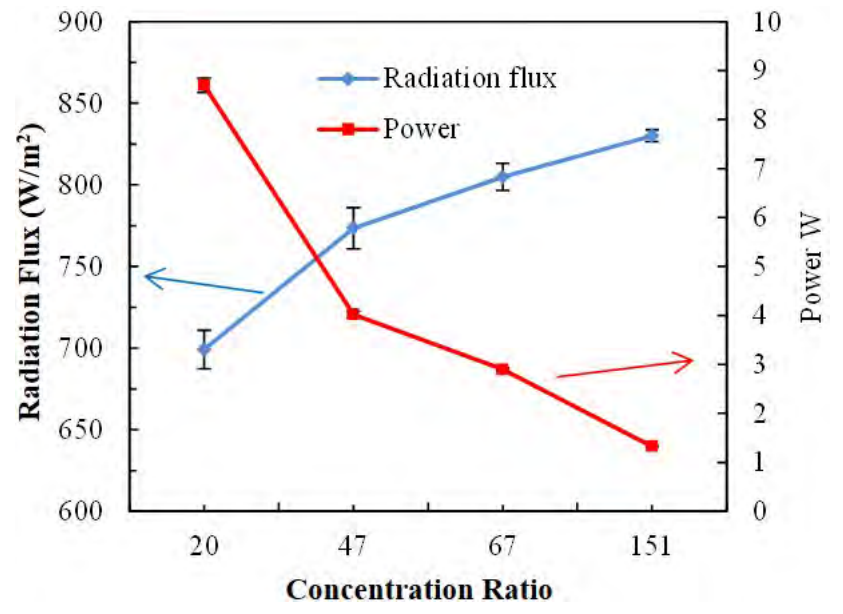

Figure 8 Radiation flux and power as a function of concentration ratio $C R$

it represents $54 \%$ of the power. Finally, the total emitted power from the opaque plate was $8.7 \mathrm{~W}$.

The energy efficiency could be greater if irregularities in curvature are less severe. Having a higher concentration of the radiation on the receiver surface is also attained by minimizing the irregularities, and this is evidenced in Figure 9.

\section{Conclusions}

In this work, the global energy efficiency and concentration ratio of a parabolic solar concentrator using thermographic image processing are determined. It was found that $C R$ can be determined with a high level of accuracy using thermographic image processing. $C R$ also varies from 20 to 151 depending on the radiation flux that is required for the heating of the receiving plate, and the thermal efficiency fluctuated during the time of experimentation, having a peak of $25 \%$ and a mean value of $15.3 \%$.

The maximum concentrated radiation flux and the maximum $C R$ are obtained just in a small central region where the temperatures are higher. However, the power is lower when the area is smaller. This behavior was caused because of the incident radiation on the plate, which is not properly concentrated. Additionally, the energy distribution is not uniform due to irregularities in the concentrator. It can be noticed that irregularities affect energy distribution and consequently energy efficiency. It could be characterized by determining the $C R$ using thermographic methods.

The irregularities of curvature in the concentrators significantly deteriorate the uniformity of the radiation 

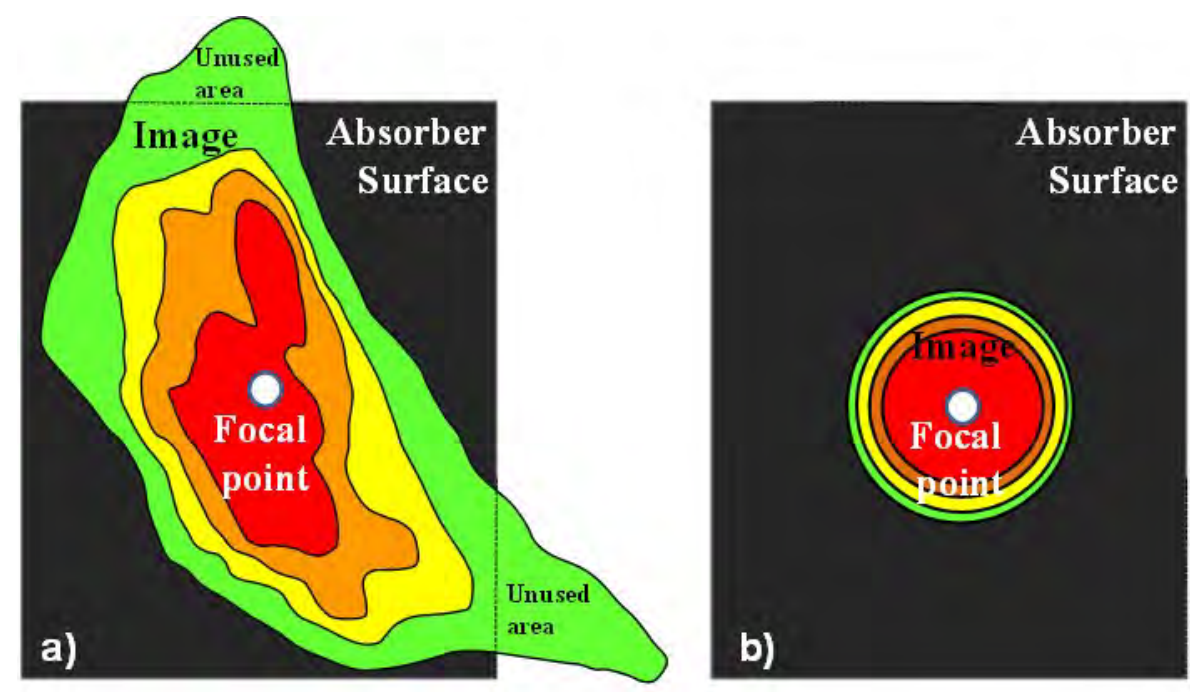

Figure $9 \mathrm{Bad}$ a) and good b) solar concentration on the absorber surface

flux and its symmetry on the receiver. Those irregularities also make energy efficiency decrease due to unused areas of concentration. Appropriate methods of manufacture should be adopted to avoid concentration factor issues.

For the optimum design of solar concentrators, it is necessary to minimize the receiver surface area in order to avoid reducing the area of reflection by generating shadows over the concentrator.

\section{Declaration of competing interest}

We declare that we have no significant competing interests, including financial or non-financial, professional, or personal interests interfering with the full and objective presentation of the work described in this manuscript.

\section{Acknowledgements}

The authors would like to acknowledge "Vicerrectoría de Investigación", Universidad de Antioquia for the valuable economic contribution toward the development of this research through the program 'Sostenibilidad' and international tickets program.

\section{References}

[1] E. Guilyardi and et al., "Ipcc special report global warming of $1.5^{\circ} \mathrm{C}$ summary for teachers," Office for Climate Education, France, Tech. Rep., Dec. 2018. [Online]. Available: https://n9.cl/ts3se

[2] C. J. Smith and et al., "Current fossil fuel infrastructure does not yet commit us to $1.5{ }^{\circ} \mathrm{C}$ warming," Nature Communications, no. 101, Jan. 15, 2019. [Online]. Available: https://doi.org/10.1038/ s41467-018-07999-w
[3] "Adoption of the paris agreement. proposal by the president. paris climate change conference-november 2015, cop 21," UNFCCC. Conference of the Parties, París, Dec. 12, 2015. [Online]. Available: https://undocs.org/en/FCCC/CP/2015/L.9/Rev.1

[4] UPME and IDEAM. (2005) Atlas de radiación solar de colombia. República de Colombia. Ministerio de Minas y Energía. [Online]. Available: https://repositoriobi.minenergia.gov.co/handle/ $123456789 / 2414$

[5] H. L. Zhang, J. Baeyens, J. Degrève, and G. Cacères, "Concentrated solar power plants: Review and design methodology," Renewable and Sustainable Energy Reviews, vol. 22, Jun. 2013. [Online]. Available: https://doi.org/10.1016/j.rser.2013.01.032

[6] Q. Li and et al., "Energy concentration limits in solar thermal heating applications," Energy, vol. 96, Feb. 1, 2016. [Online]. Available: https://doi.org/10.1016/j.energy.2015.12.057

[7] J. A. Duffie and W. A. Beckman. (2013) Solar engineering of thermal processes. John Wiley \& Sons. Inc. [Online]. Available: https://n9.cl/xewfd

[8] O. Ellabban, H. Abu-Rub, and F. Blaabjerg, "Renewable energy resources: Current status, future prospects and their enabling technology," Renewable and Sustainable Energy Reviews, vol. 39, Nov. 2014. [Online]. Available: https://doi.org/10.1016/j.rser.2014.07.113

[9] J. E. Hoffmann, "On the outlook for solar thermal hydrogen production in south africa," International Journal of Hydrogen Energy, vol. 44, no. 2, Jan. 8, 2019. [Online]. Available: https: //doi.org/10.1016/j.ijhydene.2018.11.069

[10] S. E. Hosseini, H. Barzegaravval, B. Chehroudi, and M. A. Wahid, "Hybrid solar flameless combustion system: Modeling and thermodynamic analysis," Energy Conversion and Management, vol. 166, Jun. 15, 2018. [Online]. Available: https://doi.org/10.1016/j. enconman.2018.04.012

[11] D. I. Paul, "Application of compound parabolic concentrators to solar photovoltaic conversion: A comprehensive review," International journal of energy research, vol. 43, no. 9, Apr. 1, 2019. [Online]. Available: https://doi.org/10.1002/er.4428

[12] S. M. Jeter, "The distribution of concentrated solar radiation in paraboloidal collectors," Journal of solar energy engineering, vol. 108, no. 3, Aug. 1, 1986. [Online]. Available: https://doi.org/10.1115/ 1.3268096

[13] D. Rodriguez and G. Rosengarten, "Improving the concentration ratio of parabolic troughs using a second-stage flat mirror," Applied Energy, vol. 159, Dec. 1, 2015. [Online]. Available: https: //doi.org/10.1016/j.apenergy.2015.08.106

[14] J. P. Núnez, H. Price, M. Silva, and M. Castellano, "Optical analysis of a two stage $x x$ simultaneous multiple surface concentrator for 
parametric trough primary and flat absorber with application in direct steam generation solar thermal plants," Journal of Solar Energy Engineering, vol. 138, no. 2, Apr. 2016. [Online]. Available: https://doi.org/10.1115/1.4032243

[15] J. W. Baughn and J. B. Bergquam, "Optimum concentration ratio for a solar central-receiver electric power plant," Journal of Engineering for gas Turbines and Power, vol. 99, no. 3, Jul. 1977. [Online]. Available: https://doi.org/10.1115/1.3446537

[16] D. Xu and M. Qu, "Experimental performance analysis of external compound parabolic concentrators with low concentration ratios for medium temperature applications," Energy Sustainability, Jun. 2014. [Online]. Available: https://doi.org/10.1115/ES2014-6441

[17] N. Mbodji and A. Hajji, "Performance testing of a parabolic solar concentrator for solar cooking," Journal of Solar Energy Engineering, vol. 138, no. 4, Aug. 2016. [Online]. Available: https: //doi.org/10.1115/1.4033501

[18] D. Y. Goswami and F. Kreith. (2007) Handbook of energy efficiency and renewable energy. CRC Press. Taylor \& Francis Group. Boca Ratón, FL. [Online]. Available: https://n9.cl/e95h

[19] R. Xu and et al., "Effects of deformation of cylindrical compound parabolic concentrator (cpc) on concentration characteristics," Solar Energy, vol. 176, Dec. 2018. [Online]. Available: https: //doi.org/10.1016/j.solener.2018.10.001

[20] G. Wang, F. Wang, Z. Chen, P. Hu, and R. Cao, "Experimental study and optical analyses of a multi-segment plate (msp) concentrator for solar concentration photovoltaic (cpv) system," Renewable Energy, vol. 134, Apr. 2019. [Online]. Available: https://doi.org/10. 1016/j.renene.2018.11.009

[21] H. Hoseinzadeh, A. Kasaeian, and M. B. Shafii, "Geometric optimization of parabolic trough solar collector based on the local concentration ratio using the monte carlo method," Energy Conversion and Management, vol. 175, Nov. 1, 2018. [Online]. Available: https://doi.org/10.1016/j.enconman.2018.09.001

[22] M. Vollmer and K.-P. Möllmann. (2018) Infrared thermal imaging: fundamentals, research and applications. Wiley-VCH Verlag $\mathrm{GmbH}$ \& Co. KGaA. [Online]. Available: https://n9.cl/gjxjr

[23] P. A. Funk and D. L. Larson, "Parametric model of solar cooker performance," Solar Energy, vol. 62, no. 1, Jan. 1998. [Online]. Available: https://doi.org/10.1016/S0038-092X(97)00074-1 